\section{Effect of Acylase on the Agglutinability of Human Erythrocytes}

SEveral workers have reported the inactivation of human erythrocyte agglutinogens by enzymes ${ }^{1-3}$. Acylase from hog kidney, able to hydrolyse $20,000 \mu$ moles of acetyl D,L-methionine/mg of protein nitrogen/h, specifically diminished agglutinability of human group A erythrocytes. A 2 per cont suspension of the erythrocytes in an isotonic veronal buffer solution of $p \mathrm{H} 7.35$ containing 0.25 per cent of the enzyme was incubated at $37^{\circ} \mathrm{C}$ for $3 \mathrm{~h}$. The erythrocytes were washed three times in the same buffer solution, to remove the enzyme, and tested for agglutinability with serial dilutions of human anti-A sera. Controls, consisting of erythrocytes from the same individuals, treated with the same amount of veronal buffer solution instead of the enzyme solution, wore simultaneously tested. Weak or negative agglutination was observed with the treated erythrocytes of group $A$ $\left(A_{1}, A_{2}\right.$ and also $A_{1} B$ and $A_{2} B$ ) at the higher dilutions of anti-A sera. Erythrocytes of the groups B, (), M, N, $\mathrm{D}, \mathrm{C}, \mathrm{E}, \mathrm{c}$ and $\mathrm{e}$ did not show any alteration in agghtinability caused by a similar enzymo treatment.

In absorption experiments, the group A erythrocytes treated with acylase also showed a small but consistent decrease in their ability to absorb anti-A human sera, which was not observed for other groups of erythrocytes and corresponding antisera.

Table 1. FFFECT OF ACYLASE on Agglutinability of Group A ERYthro-

\begin{tabular}{ccccc}
\multicolumn{5}{c}{ CYTES } \\
$\quad$ Cells & $1: 20$ & $1: 40$ & $1: 80$ & $1: 160$ \\
Acylase treated $A_{1}$ & 3 & 2 & 1 & 0 \\
Acylase treated $A_{2}$ & 3 & 2 & $D$ & 0 \\
Control & 4 & 4 & 3 & 1 \\
Control & 4 & 4 & 2 & 1
\end{tabular}

4 Complete agclutination: 3 , one large clumn with small ones: 2 medium sized clumps; 1, small clumps; D, doubtful clumps; 0 , no clumps visible.

The specific part of the A antigen contains $\mathrm{N}$-acetyl-Dgalactosamine as a terminal unit. ${ }^{4}$. A de-acetylation of this moisty might diminish the agglutinability of the human group A erythrocytes. The specific function of acylase is hydrolysis of esters of acetic acid, but the effect is de. creased by esterification of the alcohols with other acids ${ }^{5}$. The observed decrease in agglutinability of the group A orythrocytes was moderate or small, but quite specific and reproducible (Table 1). Further studies, by a quantitative haemagglutination technique ${ }^{6}$, to determine the degree of diminution in agglutinability of group A erythrocytes after a similar treatment with acylase are being carried out in an attempt to differentiato between the homozygous $A_{1} A_{1}$ and the heterozygous $A_{1} O$ individuals.

\section{Aparna Chattoraj}

Section of Immunology, Blocd Center,

Division of Medicine, Michael Reese Hospital and

Medical Center, 530 East 31st Street, Chicago,

Illinois.

${ }^{1}$ Race, R. R.. and Sanger, Ruth, Blood Groups in Man, third ed. (Scientiflc Publications, Oxford, 1958).

${ }^{2}$ Springer, G. F., Bart. Rev., 27, 191 (1963).

"Chattoraj, A., and Boyd, W. C., Nature, 206, 837 (1965).

- Morgan, W. T. J., and Watkins, W. M., Brit. Med. Bull., 15, 109 (1959).

'Sumner, J. B., and Myrbäck, K., The Enzymes, 1 (Academic Press Inc., New York, 1950).

'Goodman, H. S.. Nature, 193, 386 (1962).

\section{HISTOLOGY}

\section{Staining of Proteins on Cellulose Acetate}

THE following technique has been devised, based on the use of dimethyl sulphoxide as a solvent, for use when the elution of stained protcins followed by absorptiometric measurement is chosen in preferenco to the scanning of cellulose acetato strips.
After the normal electrophoretic run, the damp strips are placed directly into a dish of staining solution, consisting of 0.3 por eent Fast Green F.C.F. (Gurr) in 3 per cent aqueous trichloroacetic acid. After $10 \mathrm{~min}$ the staining solution is poured off and the strip is washed in six or eight changes of 2 per cent aqueous acetic acid, the dish being gently agitated to assist elution of the background stain.

When the background is white, the strip is dried between blotting paper over a radiator and the stained bands are cut individually and placed in test-tubes. One band of plain background is cut from the strip to act as a blank. Equal volumes of redistilled dimethyl sulphoxido (usually $5 \mathrm{ml}$.) are then added to each tube and these are corked and shaken in a mechanical agitator for $15 \mathrm{~min}$. Each solution is measured against the blank, either spectrophotometrically at the absorption peak of $630 \mathrm{~nm}$, or in a colorimeter with a suitable filter (61 or 607$)$.

The final solutions are clear; both the protein and dyo complex and the cellulose acetate completely disperse in this solvent and the rate of fading appears to be very slow (less than $0 \cdot 3$ per cent, in an hour). Known concentrations of single protein solutions can be used to calibrate the dye uptake ratios in the usual manner'.

K. G. GADD

Public Health Laboratory.

Salisbury,

Rhodesia.

\section{Induced "Shedding" of the Epidermal Langerhans's Cells}

THe epidermis of the guinea-pig contains a constant number of Langerhans's cells ${ }^{1}$ (Fig. 1A). These dendritic cells differ from melanocytes both histochemically ${ }^{2}$ and ultrastructurally ${ }^{3}$, as well as in their responses to melanogenic stimuli ${ }^{4}$. There is strong evidence to indicate that they represent a unique and independent cell population, although the problem of their nature, function and origin is not as yet settled. Any experimental approach that selectively and reproducibly induces major changes in the Langerhans's cell population probably would supply some data on these unsolved problems.

We have found that a dynamic loss of epithelium and Langerhans's cells can be obtained by means of the skinstripping technique originally described by $W^{4}$ olf $^{5}$ and extensively investigated by Pinkus ${ }^{6,7}$. Later, as the repair of the epithelium occurs, a disproportionate failure of development of the Langerhans's cell population can be noticed.

The dorsal surface of the cars of white guinea-pigs was strippod with transparent adhesive tape. Between seventeen and twonty strips were necessary to remove completely the horny layer. Specimens for biopsy were taken at various intervals from $3 \mathrm{~h}$ to 4 weeks after stripping, and Langerhans's cells were demonstrated in cryostat sections and isolated epidermal sheets by the histochemical method for ATPase $^{8}$ according to a technique described previously ${ }^{1}$.

After stripping, most of the suprabasal parts of tho epithelium were shed as a compact parakeratotic layer and with them was included almost the entire population of suprabasal Langerhans's cells (Fig. 1 $B$ ). A new acanthotic epithelium that was almost devoid of Langerhans's cells rapidly formed, the epithelium containing only those cells that had originally occupicd a position within or immediately above the basal layer. In contrast to the very rapid formation of the new epithelium, the numbor of Langerhans's cells increased only slowly within this new epidermis over a period of about 2 weeks.

This slow repopulation of the epidermis by Langerhans's cells poses the problem of their origin. Do the Langerhans's cells re-form in place by division of the fow Langerhans's cells left after the stripping? Do they form by 